\title{
Enhanced Suicidal Erythrocyte Death Contributing to Anemia in the Elderly
}

\author{
Adrian Lupescu ${ }^{a, b}$ Rosi Bissinger ${ }^{a}$ Tobias Goebel $^{b} \quad$ Madhuri S. Salker $^{a}$ \\ Kousi Alzoubi ${ }^{a}$ Guilai Liu ${ }^{a}$ Liviu Chirigiu ${ }^{b, d}$ Andreas F. Mack ${ }^{c}$ Syed M. Qadria \\ Florian Lang ${ }^{a}$
}

aDepartment of Physiology, University of Tübingen, Tübingen, 'D Division of Internal Medicine and Geriatrics, Capio Franz von Prümmer Klinik, Bad Brückenau, 'Department of Anatomy, University of Tübingen, Tübingen, Germany; ${ }^{d}$ Department of Pharmacy, University of Medicine and Pharmacy of Craiova, Craiova, Romania

\section{Key Words}

Phosphatidylserine $\cdot$ Ageing $•$ Anemia $•$ Oxidative stress $\bullet$ GSH $•$ Ceramide $•$ Eryptosis

\begin{abstract}
Background/Aims: Anemia, a common condition in the elderly, could result from impaired formation and/or from accelerated loss of circulating erythrocytes. The latter could result from premature suicidal erythrocyte death or eryptosis characterized by phosphatidylserine (PS) exposure at the erythrocyte surface. Triggers of eryptosis include increased cytosolic $\mathrm{Ca}^{2+}$ concentration $\left(\left[\mathrm{Ca}^{2+}\right]_{\mathrm{i}}\right)$, oxidative stress and ceramide. The present study explored whether eryptosis is altered in elderly individuals and, if so, to identify underlying mechanisms. Methods: Blood was drawn from healthy young ( $n=11$, age $31.3 \pm 1.7$ years) and elderly ( $n=16$, age $88.6 \pm 0.9$ years) individuals. PS exposure was estimated from annexin $V$-binding, cell volume from forward scatter, $\left[\mathrm{Ca}^{2+}\right]_{i}$ from Fluo3-fluorescence, reactive oxygen species (ROS) from 2',7'dichlorodihydrofluorescein fluorescence, reduced glutathione (GSH) from mercury orange fluorescence and ceramide from FITC-conjugated antibody binding in flow cytometry. Measurements were made in erythrocytes from freshly drawn blood and in erythrocytes exposed in vitro for $24 \mathrm{~h}$ to plasma from young or elderly individuals. Results: Elderly individuals suffered from severe anemia (hemoglobin $10.5 \pm 0.3 \mathrm{~g} / 100 \mathrm{ml}$ ) despite enhanced number of reticulocytes $(2.3 \pm 0.2 \%)$. The percentage of PS-exposing erythrocytes was significantly higher in the elderly $(2.5 \pm 0.2 \%)$ than in the young volunteers $(1.3 \pm 0.1 \%)$. The increase in PS exposure was paralleled by significant increase of ROS and significantly decreased levels of reduced GSH. Erythrocyte $\left[\mathrm{Ca}^{2+}\right]_{i}$, and ceramide abundance tended to be higher in the elderly, differences, however, not reaching statistical significance. Conclusions: The anemia of elderly individuals is mainly if not exclusively due to enhanced eryptosis, resulting at least in part from GSH deficiency and increased oxidative stress.

Copyright $\odot 2015$ S. Karger AG, Basel
\end{abstract}

A. Lupescu and R. Bissinger contributed equally and thus share first authorship.

Prof. Dr. Florian Lang

KARGER 125
Physiologisches Institut der Universität Tübingen

Gmelinstr. 5, D-72076 Tübingen (Germany)

Tel. +49 707129 72194, Fax +49 707129 5618, E-Mail florian.lang@uni-tuebingen.de 


\begin{tabular}{|c|c|c|}
\hline Cellular Physiology & Cell Physiol Biochem 2015;36:773-783 & \\
\hline and Biochemistry & $\begin{array}{l}\text { DOI: 10.1159/000430137 } \\
\text { Published online: May 22, } 2015\end{array}$ & $\begin{array}{l}\text { O } 2015 \text { S. Karger AG, Basel } \\
\text { www.karger.com/cpb }\end{array}$ \\
\hline
\end{tabular}

\section{Introduction}

Anemia is a common condition in the elderly and affects more than $50 \%$ individuals who are older than the age of 80 years [1]. The prevalence of anemia increases with age and sharply increases in the octogenarian and centenarian cohorts [2]. In the majority of the elderly population, the etiology of anemia remains elusive [3]. Anemia in the elderly is associated with decreased life quality, enhanced morbidity, and increased mortality $[1,4$, 5]. In principle, anemia could result from impaired formation or from accelerated loss of erythrocytes.

Accelerated loss of erythrocytes could result from suicidal cell death or eryptosis, which is characterized by cell shrinkage [6] and cell membrane scrambling with exposure of phosphatidylserine at the cell surface [7].

Signaling involved in the stimulation of eryptosis includes increase of cytosolic $\mathrm{Ca}^{2+}$ activity $\left(\left[\mathrm{Ca}^{2+}\right]_{\mathrm{i}}\right)[7]$, formation of ceramide [8], oxidative stress [7], energy depletion [7], caspase activation [9-13], activation of kinases such as casein kinase $1 \alpha$ [14, 15], Janusactivated kinase JAK3 [16], protein kinase C [17], or p38 kinase [18], as well as inhibition or knockout of further kinases including AMP-activated kinase AMPK [19], cGMP-dependent protein kinase [10], PAK2 kinase [20], as well as sorafenib- and sunitinib-sensitive kinases $[21,22]$.

Eryptosis could be triggered by a wide variety of xenobiotics $[7,8,21-68]$ and accelerated eryptosis is observed in several clinical pathologies including sepsis, malaria, sickle cell disease, Wilson's disease, malignancy, metabolic syndrome, diabetes, hepatic and renal insufficiency, hemolytic uremic syndrome, dehydration, hyperphosphatemia as well as phosphate depletion $[7,49,69,70]$.

The present study tested, whether eryptosis is altered in the elderly. To this end, phosphatidylserine surface abundance, cell volume, $\left[\mathrm{Ca}^{2+}\right]_{i}$, oxidative stress, GSH abundance and ceramide abundance were determined in erythrocytes drawn from elderly and young volunteers.

\section{Materials and Methods}

Patients, erythrocytes and treatments

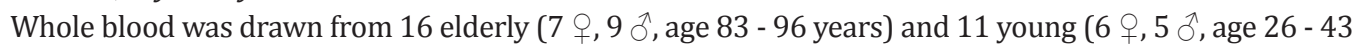
years) volunteers. The elderly were recruited from the patients at the Division of Internal Medicine and Geriatrics, Capio Franz von Prümmer Klinik. The clinical characteristics of the elderly are shown in table 1 . The study was approved by the ethics committee of the University of Tübingen (184/2003V). Both, elderly and young volunteers provided written informed consent. In order to isolate erythrocytes, whole blood was centrifuged at $120 \mathrm{~g}$ for $20 \mathrm{~min}$ at $23^{\circ} \mathrm{C}$ and the platelets and leukocytes-containing supernatant was disposed.

Measurements were made in isolated erythrocytes or in erythrocytes ( $0^{-}$blood group) from healthy young individuals incubated in vitro with $500 \mu \mathrm{l}$ plasma from young or elderly volunteers at a hematocrit of $0.4 \%$ for $24 \mathrm{~h}$. For all measurements 50.000 cells were counted.

\section{Analysis of annexin-V-binding and forward scatter}

In order to determine Annexin-V-binding, $2 \mu \mathrm{l}$ of freshly drawn blood was mixed in $500 \mu \mathrm{l}$ Ringer solution containing $5 \mathrm{mM} \mathrm{CaCl}_{2}$ and subsequently stained with Annexin-V-FITC (1:200 dilution; ImmunoTools, Friesoythe, Germany) and incubated at $37^{\circ} \mathrm{C}$ for 20 min under protection from light. Using Flow cytometry, the forward scatter (FSC) of the erythrocytes was determined and Annexin-V-FITC fluorescence intensity was measured with an excitation wavelength of $488 \mathrm{~nm}$ and an emission wavelength of $530 \mathrm{~nm}$ using a FACS Calibur (BD, Heidelberg, Germany).

Measurement of intracellular $\mathrm{Ca}^{2+}$

To quantify intracellular $\mathrm{Ca}^{2+}, 2 \mu \mathrm{l}$ of freshly drawn blood was mixed in $500 \mu$ l Ringer solution containing $5 \mathrm{mM} \mathrm{CaCl}_{2}$, stained with Fluo-3/AM ( $5 \mu \mathrm{M}$; Biotium, Hayward, USA) and incubated at $37^{\circ} \mathrm{C}$ for 


\section{Cellular Physiology Cell Physiol Biochem 2015;36:773-783 \begin{tabular}{l|l} 
and Biochemistry Published online: May 22, 2015 & $\begin{array}{l}\text { C 2015 S. Karger AG, Basel } \\
\text { www.karger.com/cpb }\end{array}$ \\
\hline
\end{tabular} \\ Lupescu et al.: Eryptosis in the Elderly}

$30 \mathrm{~min} . \mathrm{Ca}^{2+}$-dependent fluorescence intensity was measured with an excitation wavelength of $488 \mathrm{~nm}$ and an emission wavelength of $530 \mathrm{~nm}$ on a FACS Calibur.

Determination of ceramide formation

To determine ceramide abundance, a monoclonal antibody-based assay was used. Four $\mu$ l erythrocytes were mixed in $1 \mathrm{ml}$ Ringer. From the resulting cell suspension $100 \mu \mathrm{l}$ was centrifuged (1600 rpm for 3 mins at RT) pelleting the erythrocytes. Subsequently, cells were stained for $1 \mathrm{~h}$ at $37^{\circ} \mathrm{C}$ with $1 \mu \mathrm{g} / \mathrm{ml}$ anti-ceramide antibody (1:10 dilution; clone MID 15B4; Alexis, Grünberg, Germany) in phosphate-buffered saline (PBS) containing $0.1 \%$ bovine serum albumin (BSA). After two washing steps with $100 \mu \mathrm{l}$ PBS-BSA, cells were stained for $30 \mathrm{~min}$ with polyclonal fluorescein-isothiocyanate (FITC)-conjugated goat anti-mouse IgG and IgM specific antibody (1:50 dilution; BD Pharmingen, Hamburg, Germany) in PBS-BSA. Unbound secondary antibody was removed by repeated washing with $50 \mu \mathrm{l}$ PBS-BSA. The samples were resuspended in 200 $\mu \mathrm{l}$ PBS-BSA and then analyzed by flow cytometric analysis at an excitation wavelength of $488 \mathrm{~nm}$ and an emission wavelength of $530 \mathrm{~nm}$ on a FACS Calibur.

Quantification of reactive oxidant species (ROS)

Oxidative stress was determined utilizing 2',7'-dichlorodihydrofluorescein diacetate (DCFDA). Four $\mu \mathrm{l}$ erythrocytes were mixed in $1 \mathrm{ml}$ Ringer. From the resulting cell suspension $150 \mu \mathrm{l}$ was centrifuged (1600 rpm for 3 mins at RT). Cells were stained with DCFDA (10 $\mu$; Sigma, Schnelldorf, Germany) in Ringer solution at $37^{\circ} \mathrm{C}$ for $30 \mathrm{~min}$ and then washed three times in $150 \mathrm{ul}$ Ringer solution. The DCFDA-loaded erythrocytes were resuspended in $200 \mu$ l Ringer solution and ROS-dependent fluorescence intensity was measured at an excitation wavelength of $488 \mathrm{~nm}$ and an emission wavelength of $530 \mathrm{~nm}$ on a FACS Calibur.

\section{Determination of GSH abundance}

The content of reduced glutathione was determined using mercury orange. Four $\mu$ l erythrocytes were mixed in $1 \mathrm{ml}$ Ringer. From the resulting cell suspension $150 \mu \mathrm{l}$ was centrifuged (1600 rpm for 3 mins at RT). Cells were stained with mercury orange in PBS ( $40 \mu \mathrm{M}$, Sigma Aldrich, Germany) and incubated for 3 $\min$ at $37^{\circ} \mathrm{C}$, washed once and resuspended in $200 \mu \mathrm{PBS}$. The fluorescence intensity was measured with flow cytometry at an excitation wavelength of $488 \mathrm{~nm}$ and an emission wavelength of $576 \mathrm{~nm}$.

\section{Microscopy}

For the visualization of eryptotic erythrocytes, $20 \mu$ l erythrocytes $\left(1 \times 10^{6}\right.$ cells $)$ were fixed in methanol/ acetone and subsequently stained with Annexin V-FLUOS (1:100 dilution; Roche Diagnostics, Mannheim, Germany) in $200 \mu$ l Ringer solution containing $5 \mathrm{mM} \mathrm{CaCl}_{2}$. The erythrocytes were washed twice and finally resuspended in $200 \mu \mathrm{l}$ Ringer solution containing $5 \mathrm{mM} \mathrm{CaCl}$. Forty $\mu \mathrm{l}$ were placed with PROlong Gold antifade reagent (Invitrogen, Darmstadt Germany) onto a glass slide, covered with a coverslip and images were taken on a Zeiss LSM 5 EXCITER confocal laser-scanning microscope or with the phase light (Carl Zeiss MicroImaging, Germany) with a water immersion Plan-Neofluar 40/1.3 NA DIC. Scale bar $5 \mu$ m.

\section{Statistics}

Data are expressed as arithmetic means \pm SEM. Mann-Whitney test, Spearman nonparametric analysis and Student's $t$-test were performed to determine statistical significance between the two groups using Graph Pad Prism version 6.00 for Windows, GraphPad Software, La Jolla California USA; n denotes the number of individuals. $P<0.05$ was considered significant.

\section{Results}

From the 16 elderly participants, 10 individuals were anemic with a hemoglobin level lower than $11 \mathrm{~g} / \mathrm{dl}$. None of the young volunteers was found to be anemic. As evident from Table 1, the average erythrocyte number, hematocrit and hemoglobin concentration were all decreased in the elderly as compared to the young volunteers or to the respective control values. The anemia of the elderly was paralleled by significantly enhanced reticulocytosis, indicating enhanced erythrocyte turnover. As illustrated in Fig. 1A, the percentage of 
Table 1. Characteristics of the volunteers. Values are given as arithmetic mean \pm SEM. $\left({ }^{*} P<0.05\right.$, ${ }^{* *} P<0.01,{ }^{* * *} P<0.001$, n.s.; non significant) indicates significant difference from healthy young volunteers using Student's $t$-test

\begin{tabular}{|c|c|c|}
\hline & Elderly & Control \\
\hline Age & $88.6 \pm 0.9$ years (range $83-96$ ) & $\begin{array}{l}31.3 \pm 1.7 \text { years } \\
\text { (range } 26-43 \text { ) }\end{array}$ \\
\hline Gender distribution & 7 females, 9 males & 6 females, 5 males \\
\hline Plasma creatinine concentration & $1.3 \pm 0.1 \mathrm{mg} / 100 \mathrm{ml}$ & $1.0 \pm 0.1 \mathrm{mg} / 100 \mathrm{ml}$ \\
\hline Plasma ferritin concentration & $169.6 \pm 47.5 \mu \mathrm{g} / 100 \mathrm{ml}^{*}$ & $48.9 \pm 8.8 \mu \mathrm{g} / 100 \mathrm{ml}$ \\
\hline Transferrin saturation & $33.4 \pm 7.5 \%$ & $31.8 \pm 3.2 \%$ \\
\hline Erythrocyte number & $3.5 \pm 0.1 \times 10^{6} / \mu \mathrm{l} * * *$ & $4.8 \pm 0.1 \times 10^{6} / \mu l$ \\
\hline Hematocrit & $31.5 \pm 0.8 \% * * *$ & $42.2 \pm 1.0 \%$ \\
\hline Hemoglobin & $10.5 \pm 0.3 \mathrm{~g} / 100 \mathrm{ml} * * *$ & $14.5 \pm 0.4 \mathrm{~g} / 100 \mathrm{ml}$ \\
\hline Reticulocytes (\%) & $2.3 \pm 0.2 \% * * *$ & $0.9 \pm 0.1 \%$ \\
\hline Reticulocytes & $77.5 \pm 6.6 \times 10^{3} / \mu \mathrm{l} * * *$ & $45.4 \pm 3.6 \times 10^{3} / \mu \mathrm{l}$ \\
\hline Hemoglobin/ reticulocyte & $0.9 \pm 0.2 \mathrm{pg} /$ cell $* *$ & $1.7 \pm 0.1 \mathrm{pg} /$ cell \\
\hline Diagnoses & $\begin{array}{l}\text { Type } 2 \text { diabetes mellitus }(n=7) \text {, hypertension } \\
(n=12) \text {, chronic kidney disease }(C K D) \text { stage } 2(n=6) \text {, } \\
\text { CKD stage } 3(n=6) \text {, CKD stage } 4(n=2) \text {, dialysis } \\
(n=0), \text { hepatic insufficiency }(n=4) \text {, heart failure } \\
(n=4) \text {, myocardial infarction }(n=1) \text {, malignancy } \\
(n=5) \text {, stroke }(n=5)\end{array}$ & none \\
\hline
\end{tabular}

Fig. 1. Phosphatidylserine-exposure of erythrocytes from young and elderly volunteers. A. The percentage reticulocytes as a function of hemoglobin concentration $[\mathrm{g} / \mathrm{dl}]$ in elderly individuals $(P=* * * *$, $\mathrm{R}^{2}=0.6022$ ) using Spearman nonparametric analysis. B. Light Phase microscopy (upper panels, red arrows indicate abnormal erythrocytes)
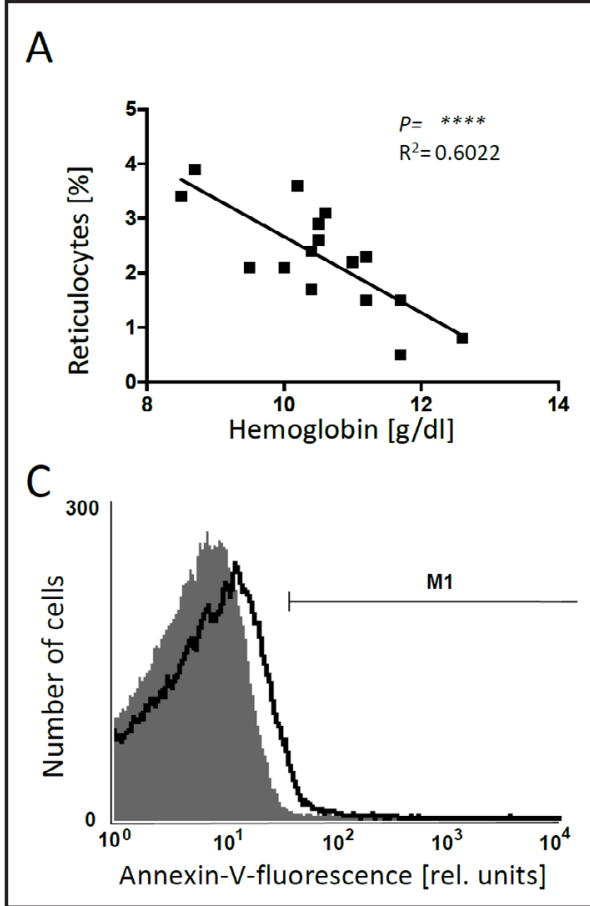

\section{B}

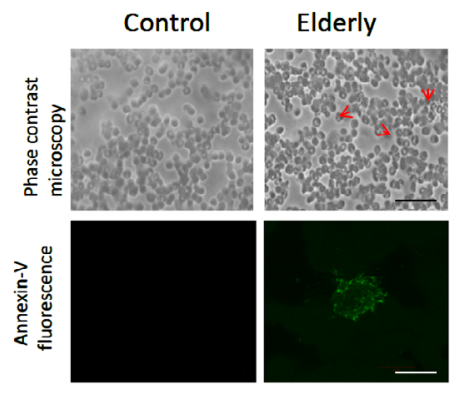

D

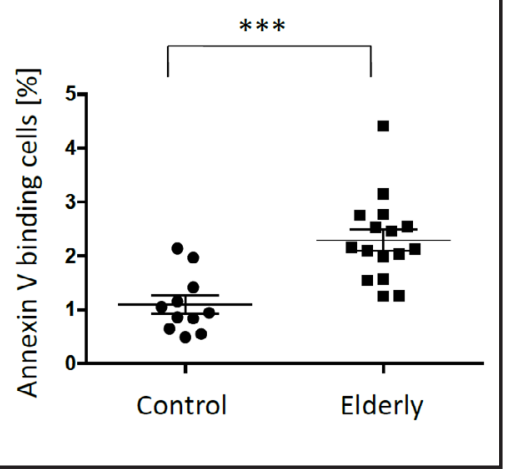

and confocal images of erythrocytes stained with Annexin V-FLUOS (green; lower panels, scale bar $5 \mu \mathrm{m}$ ). The specimens were obtained from young healthy (left panels) and from elderly (right panels) individuals. C. Original representative histogram of Annexin V-binding of erythrocytes in freshly drawn blood from young healthy (grey) and from elderly (black) volunteers. M1 indicates the Annexin-V-fluoresence defining the percentage of Annexin-V-binding erythrocytes. D. Arithmetic means \pm SEM $(n=11-16)$ of the percentage of Annexin V-binding erythrocytes in freshly drawn blood from healthy young (control, black circles) and elderly (black squares) individuals. ${ }^{* * *}(P<0.001)$ indicates significant difference from healthy young volunteers. (Mann-Whitney test).

reticulocytes in the elderly individuals was inversely and significantly correlated with the hemoglobin concentration $\left(\mathrm{R}^{2}=0.6022 ; P=0.0004\right)$. Taken together, increased erythrocyte turnover rather than decreased erythrocyte formation accounts for anemia in the elderly. 

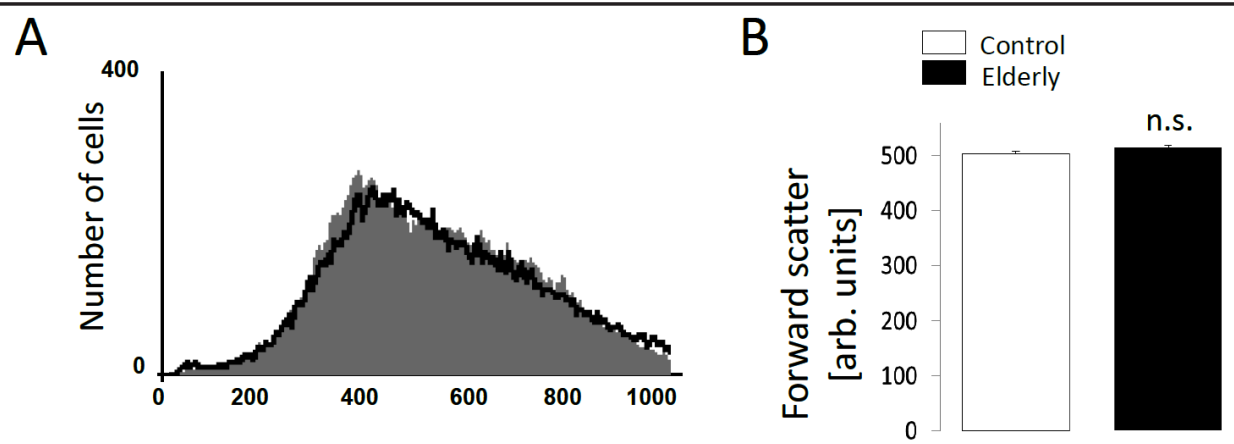

Forward scatter [rel. units]

Fig. 2. Forward scatter of erythrocytes from young and elderly volunteers. A. Original representative histogram of erythrocyte forward scatter in freshly drawn blood from young healthy (grey area) and from elderly (black line) volunteers. B. Arithmetic means \pm SEM $(n=11-16)$ of the forward scatter of erythrocytes in freshly drawn blood from healthy young (control, white bar) and elderly (black bar) individuals (n.s. indicates non significant difference using Student's $t$ - test).

The present study thus explored whether anemia of the elderly could in part be due to enhanced eryptosis. Eryptotic erythrocytes were identified by annexin-V-binding reflecting exposure of phosphatidylserine at the erythrocyte surface. As illustrated in Fig. 1B-D, the percentage of erythrocytes binding Annexin V was significantly higher in blood drawn from elderly individuals than in blood drawn from the control group. Confocal microscopy visualized the fluorescent labeled (green) Annexin $V$ at the erythrocyte surface from elderly patients (Fig. 1B). Representative histograms of Annexin V abundance at the erythrocyte surface ars shown in Fig. 1C. The percentage of Annexin V-binding erythrocytes was significantly higher in elderly patients than in young healthy volunteers (Fig. 1D).

In order to determine whether eryptosis is triggered by a plasma-borne component, erythrocytes from young healthy volunteers were exposed to plasma drawn from either, elderly patients or young healthy volunteers. As a result, the percentage of PS exposing erythrocytes drawn from young healthy individuals tended to be higher in plasma from elderly patients $(12.6 \pm 1.7 \%, \mathrm{n}=16)$ as compared to incubation in plasma from young healthy individuals $(8.8 \pm 1.4 \%, \mathrm{n}=11)$, an effect, however, not reaching statistical significance.

Forward scatter was determined in order to estimate cell volume of erythrocytes from the control group and from elderly individuals. As illustrated in Fig. 2, the average forward scatter was not significantly different between erythrocytes from elderly patients and erythrocytes from young healthy individuals.

Fluo3 fluorescence was employed to estimate $\left[\mathrm{Ca}^{2+}\right]_{i}$ in freshly drawn blood from elderly patients and young healthy volunteers. The Fluo3 fluorescence tended to be higher in erythrocytes from elderly patients compared to young healthy individuals. The difference did, however, not reach statistical significance (Fig. 3).

A further series of experiments elucidated the role of oxidative stress. To this end, generation of reactive oxygen species (ROS) was determined utilizing 2',7'-dichlorodihydrofluorescein diacetate (DCFDA) fluorescence. As illustrated in Fig. 4, DCFDA-fluorescence was significantly higher in erythrocytes drawn from elderly patients than in erythrocytes drawn from young healthy volunteers.

To determine whether oxidative stress is triggered by a plasma-borne component, erythrocytes from young healthy volunteers ( $\mathrm{O}$ - blood group) were exposed to plasma drawn from either, elderly patients or young healthy volunteers. As a result, the DCFDA fluorescence in erythrocytes drawn from young healthy individuals was similar following incubation in plasma from elderly patients $(11.1 \pm 0.5$ a.u., $\mathrm{n}=16)$ and following incubation in plasma from young healthy individuals $(11.0 \pm 0.1$ a.u., $\mathrm{n}=11)$.

The enhanced oxidative stress could have resulted from decreased GSH levels leading to impaired anti-oxidative defense. Thus, mercury orange staining was employed to quantify 


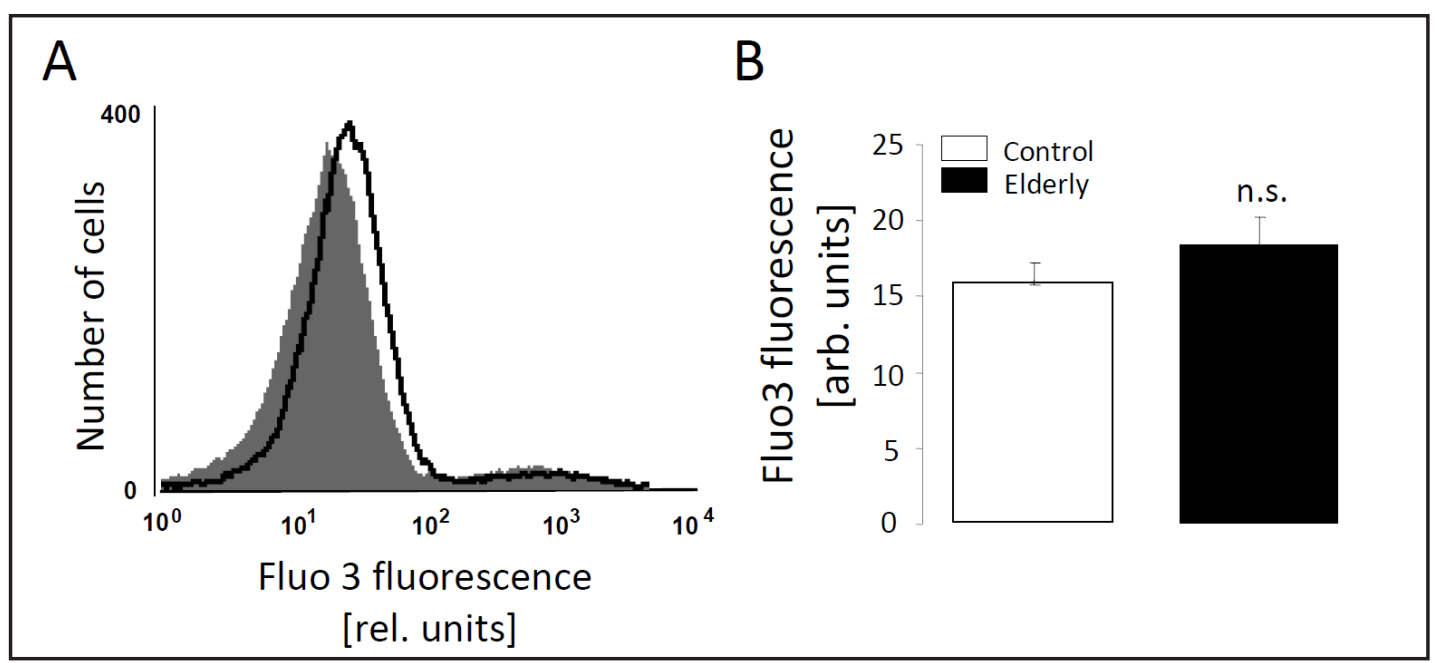

Fig. 3. Intracellular $\mathrm{Ca}^{2+}$ activity of erythrocytes from young and elderly volunteers. A. Original histogram of Fluo3 fluorescence of erythrocytes in freshly drawn blood from young healthy (grey area) and from elderly (black line) volunteers. B. Arithmetic means \pm SEM $(n=11$ - 16) of the Fluo3 fluorescence of erythrocytes in freshly drawn blood from healthy young (control, white bar) and elderly (black bar) individuals. (n.s. indicates non significant difference using Student's $t$ - test).

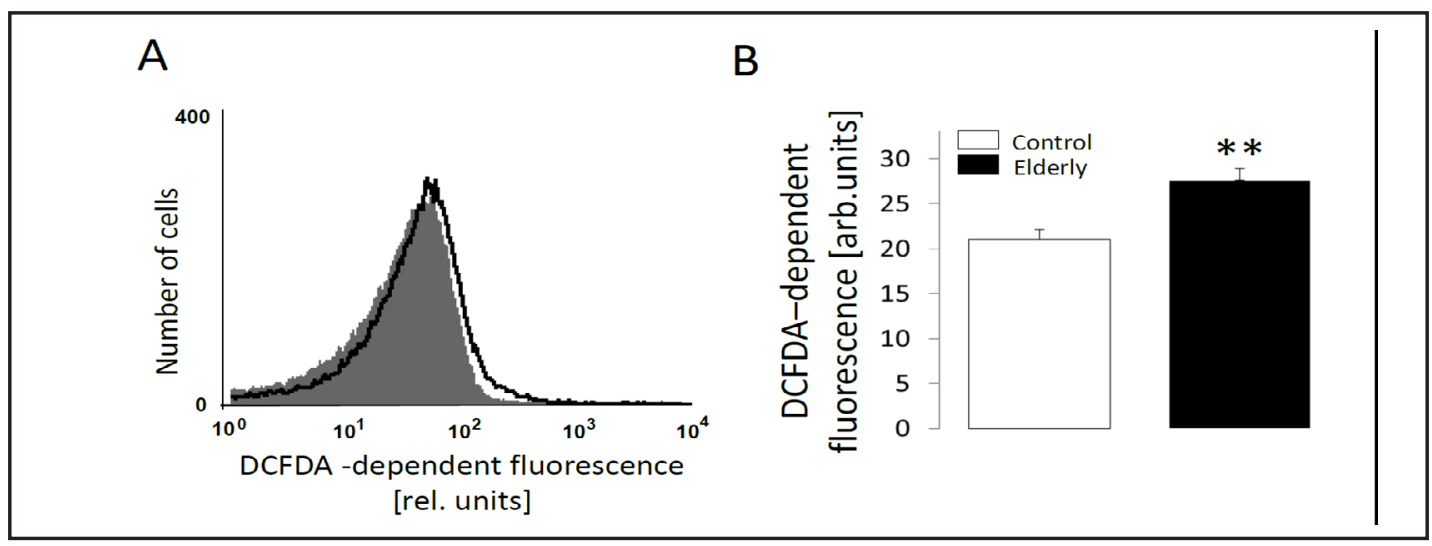

Fig. 4. Reactive oxygen species of erythrocytes from young and elderly volunteers. A. Original representative histogram of DCFDA fluorescence of erythrocytes in freshly drawn blood from young healthy (grey area) and from elderly (black line) volunteers. B. Arithmetic means \pm SEM $(n=11-16)$ of the DCFDA fluorescence of erythrocytes in freshly drawn blood from healthy young (control, white bar) and elderly (black bar) individuals. ${ }^{* *}(P<0.01)$ indicates significant difference from healthy young volunteers using Student's $t$ - test.

GSH abundance. As illustrated in Fig. 5, the mercury orange-dependent fluorescence was significantly lower in erythrocytes drawn from elderly patients than in erythrocytes drawn from young healthy volunteers.

In a next series of experiments, erythrocytes were stained with FITC-labeled antibodies to quantify ceramide using flow cytometry. As shown in Fig. 6, ceramide abundance tended to be higher in erythrocytes drawn from elderly patients than in erythrocytes drawn from young healthy volunteers, a difference, however, not reaching statistical significance.

\section{Discussion}

The present observations disclose accelerated suicidal erythrocyte death in elderly individuals. Phosphatidylserine exposure at the cell surface is the hallmark of eryptosis, the 

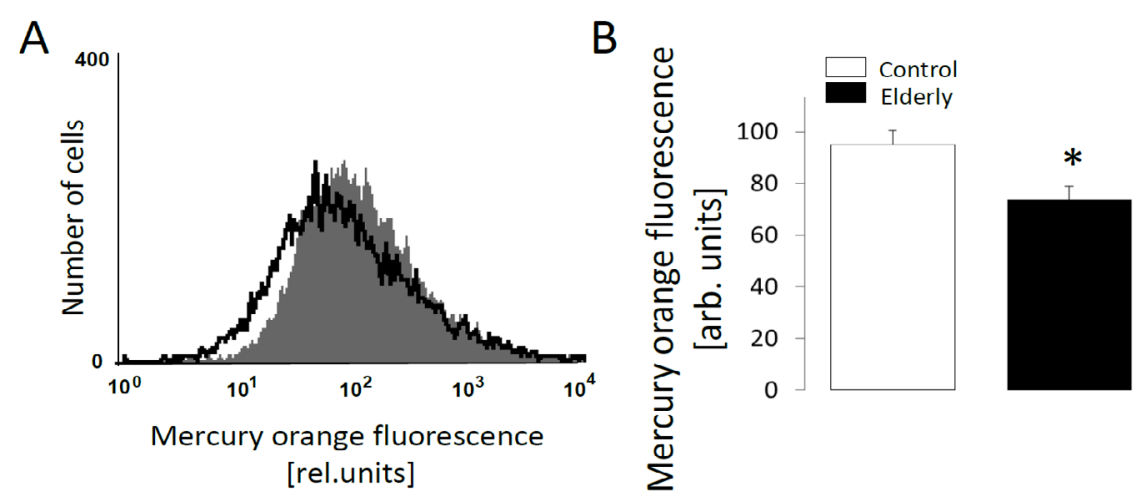

Fig. 5. GSH levels of erythrocytes from young and elderly volunteers. A. Original representative histogram of mercury orange fluorescence of erythrocytes in freshly drawn blood from young healthy (grey area) and from elderly (black line) volunteers. B. Arithmetic means \pm SEM $(n=11$ - 16) of the mercury orange fluorescence of erythrocytes in freshly drawn blood from healthy young (control, white bar) and elderly (black bar) individuals. ${ }^{*}(P<0.05)$ indicates significant difference from healthy young volunteers using Student's $t$ - test.

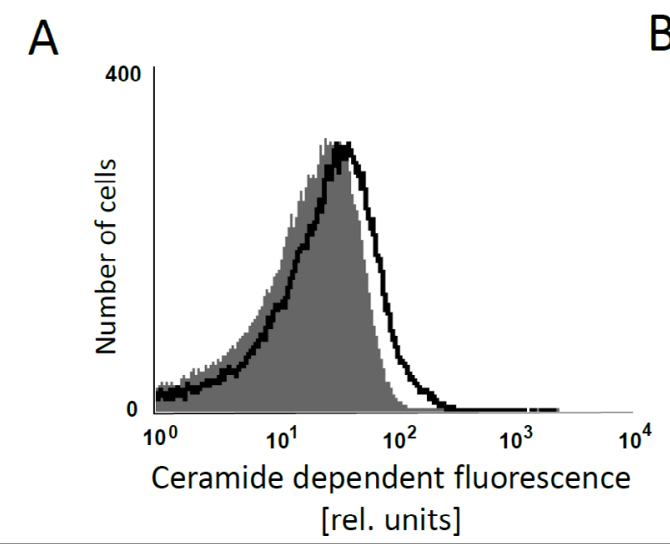

\section{B}

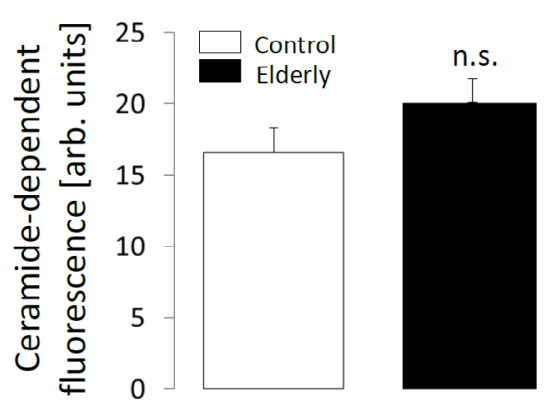

Fig. 6. Ceramide abundance of erythrocytes from young and elderly volunteers. A. Original representative histogram of ceramide-dependent FITC fluorescence of erythrocytes in freshly drawn blood from young healthy (grey area) and from elderly (black line) volunteers. B. Arithmetic means \pm SEM ( $n=11-16)$ of ceramide-dependent FITC fluorescence of erythrocytes in freshly drawn blood from healthy young (control, white bar) and elderly (black bar) individuals (n.s. indicates non significant difference using Student's $t$ test).

suicidal death of erythrocytes [7]. The percentage of erythrocytes with phosphatidylserine translocation to the erythrocyte surface was significantly enhanced in blood drawn from elderly individuals.

The enhanced cell membrane scrambling in erythrocytes drawn from elderly individuals was not paralleled by a significant decrease of cell volume. Erythrocyte $\left[\mathrm{Ca}^{2+}\right]_{\mathrm{i}}$ in elderly individuals tended to be higher as compared to erythrocytes drawn from younger individuals, a difference, however, not reaching statistical significance. Following various other triggers of eryptosis, erythrocytes decrease their volume at least in part by increase of $\left[\mathrm{Ca}^{2+}\right]_{\mathrm{i}}$ with subsequent activation of $\mathrm{Ca}^{2+}$ sensitive $\mathrm{K}^{+}$channels, $\mathrm{K}^{+}$exit, hyperpolarization of the cell membrane, $\mathrm{Cl}^{-}$exit and thus cellular loss of $\mathrm{KCl}$ with osmotically obliged water [6].

The enhanced eryptosis in elderly individuals was paralleled by increased oxidative stress paralleled by a decreased GSH abundance. Oxidative stress is a well-known stimulator of eryptosis [7]. The present observations do not allow safe conclusions as to the cause of enhanced oxidative stress. 
In some elderly individuals accelerated eryptosis could have resulted from underlying disease rather than age per se. Eryptosis is fostered by several disorders encountered in elderly individuals, such as malignancy, metabolic syndrome, diabetes, renal insufficiency or dehydration $[7,49]$. In the elderly individuals renal function was moderately decreased. However, the difference between plasma creatinine levels between the young volunteers and elderly patients was not significant and none of the elderly patients were on dialysis. According to Fig, 1D, the percentage of phosphatidylserine exposing erythrocytes was higher in each elderly individual than the average of the young individuals. Morbidity presumably contributed to but hardly accounted for the increased eryptosis in the elderly individuals.

Whatever the reason for the anemia, the enhanced eryptosis may well contribute to the ongoing anemia in elderly individuals, as eryptotic erythrocytes are rapidly removed by phagocytosis. Anemia develops as soon as the rate of eryptosis exceeds the formation of new erythrocytes [7]. Interestingly, according to the reticulocyte numbers, the formation of new erythrocytes appears to be accelerated in the elderly. Anemia in the elderly is thus not the result of impaired erythropoiesis but rather a consequence of enhanced suicidal erythrocyte death.

Eryptosis is similarly enhanced in the rapidly ageing Klotho-deficient mice [71]. Lack of Klotho is associated with increased oxidative stress [72]. It is thus tempting to speculate that accelerated eryptosis parallels oxidative stress and ageing in both, humans and mice. Additional studies are warranted to confirm this possibility.

Phosphatidylserine exposing erythrocytes could interfere with microcirculation $[8,73-$ 77] due to binding of phosphatidylserine to endothelial CXCL16/SR-PSO and subsequent adherance of eryptotic erythrocytes to the vascular wall [28]. Moreover, phosphatidylserine exposing erythrocytes stimulate blood clotting and thrombosis $[73,78,79]$. The subsequently increased cardiovascular risk could contribute to the enhanced morbidity and mortality of anemic elderly individuals.

Taken together, our observations suggest that erythrocyte cell membrane scrambling with phosphatidylserine translocation to the erythrocyte surface is enhanced and may well contribute to the anemia in elderly individuals.

\section{Disclosure Statement}

No conflict of interest.

\section{Acknowledgements}

The authors acknowledge the meticulous preparation of the manuscript by Tanja Loch. The study was supported by the Deutsche Forschungsgemeinschaft and Open Access Publishing Fund of Tuebingen University.

\section{References}

1 Berliner N: Anemia in the elderly. Trans Am Clin Climatol Assoc 2013;124:230-237.

2 Haslam A, Hausman DB, Johnson MA, Davey A, Poon LW, Allen RH, Stabler SP, Georgia Centenarian S: Prevalence and predictors of anemia in a population-based study of octogenarians and centenarians in Georgia. J Gerontol A Biol Sci Med Sci 2012;67:100-106.

3 Artz AS, Thirman MJ: Unexplained anemia predominates despite an intensive evaluation in a racially diverse cohort of older adults from a referral anemia clinic. J Gerontol A Biol Sci Med Sci 2011;66:925-932.

4 Penninx BW, Pahor M, Woodman RC, Guralnik JM: Anemia in old age is associated with increased mortality and hospitalization. J Gerontol A Biol Sci Med Sci 2006;61:474-479.

5 Goodnough LT, Schrier SL: Evaluation and management of anemia in the elderly. Am J Hematol 2014;89:8896.

6 Lang PA, Kaiser S, Myssina S, Wieder T, Lang F, Huber SM: Role of Ca2+-activated K+ channels in human erythrocyte apoptosis. Am J Physiol Cell Physiol 2003;285:C1553-C1560. 
7 Lang E, Qadri SM, Lang F: Killing me softly - suicidal erythrocyte death. Int J Biochem Cell Biol 2012;44:1236-1243.

8 Abed M, Towhid ST, Mia S, Pakladok T, Alesutan I, Borst O, Gawaz M, Gulbins E, Lang F: Sphingomyelinaseinduced adhesion of eryptotic erythrocytes to endothelial cells. Am J Physiol Cell Physiol 2012;303:C991999.

9 Bhavsar SK, Bobbala D, Xuan NT, Foller M, Lang F: Stimulation of suicidal erythrocyte death by alpha-lipoic acid. Cell Physiol Biochem 2010;26:859-868.

10 Foller M, Feil S, Ghoreschi K, Koka S, Gerling A, Thunemann M, Hofmann F, Schuler B, Vogel J, Pichler B, Kasinathan RS, Nicolay JP, Huber SM, Lang F, Feil R: Anemia and splenomegaly in cGKI-deficient mice. Proc Natl Acad Sci USA 2008;105:6771-6776.

11 Foller M, Mahmud H, Gu S, Wang K, Floride E, Kucherenko Y, Luik S, Laufer S, Lang F: Participation of leukotriene C(4) in the regulation of suicidal erythrocyte death. J Physiol Pharmacol 2009;60:135-143.

12 Lau IP, Chen H, Wang J, Ong HC, Leung KC, Ho HP, Kong SK: In vitro effect of CTAB- and PEG-coated gold nanorods on the induction of eryptosis/erythroptosis in human erythrocytes. Nanotoxicology 2012;6:847856.

13 Maellaro E, Leoncini S, Moretti D, Del Bello B, Tanganelli I, De Felice C, Ciccoli L: Erythrocyte caspase-3 activation and oxidative imbalance in erythrocytes and in plasma of type 2 diabetic patients. Acta Diabetol 2013;50:489-495.

14 Kucherenko Y, Zelenak C, Eberhard M, Qadri SM, Lang F: Effect of casein kinase 1alpha activator pyrvinium pamoate on erythrocyte ion channels. Cell Physiol Biochem 2012;30:407-417.

15 Zelenak C, Eberhard M, Jilani K, Qadri SM, Macek B, Lang F: Protein kinase CK1alpha regulates erythrocyte survival. Cell Physiol Biochem 2012;29:171-180.

16 Bhavsar SK, Gu S, Bobbala D, Lang F: Janus kinase 3 is expressed in erythrocytes, phosphorylated upon energy depletion and involved in the regulation of suicidal erythrocyte death. Cell Physiol Biochem 2011;27:547-556.

17 Klarl BA, Lang PA, Kempe DS, Niemoeller OM, Akel A, Sobiesiak M, Eisele K, Podolski M, Huber SM, Wieder T, Lang F: Protein kinase $C$ mediates erythrocyte "programmed cell death" following glucose depletion. Am J Physiol Cell Physiol 2006;290:C244-C253.

18 Gatidis S, Zelenak C, Fajol A, Lang E, Jilani K, Michael D, Qadri SM, Lang F: p38 MAPK activation and function following osmotic shock of erythrocytes. Cell Physiol Biochem 2011;28:1279-1286.

19 Foller M, Sopjani M, Koka S, Gu S, Mahmud H, Wang K, Floride E, Schleicher E, Schulz E, Munzel T, Lang F: Regulation of erythrocyte survival by AMP-activated protein kinase. FASEB J 2009;23:1072-1080.

20 Zelenak C, Foller M, Velic A, Krug K, Qadri SM, Viollet B, Lang F, Macek B: Proteome analysis of erythrocytes lacking AMP-activated protein kinase reveals a role of PAK2 kinase in eryptosis. J Proteome Res 2011;10:1690-1697.

21 Shaik N, Lupescu A, Lang F: Sunitinib-sensitive suicidal erythrocyte death. Cell Physiol Biochem 2012;30:512-522.

22 Lupescu A, Jilani K, Zelenak C, Zbidah M, Qadri SM, Lang F: Hexavalent chromium-induced erythrocyte membrane phospholipid asymmetry. Biometals 2012;25:309-318.

23 Abed M, Feger M, Alzoubi K, Pakladok T, Frauenfeld L, Geiger C, Towhid ST, Lang F: Sensitization of erythrocytes to suicidal erythrocyte death following water deprivation. Kidney Blood Press Res 2013;37:567-578.

24 Ahmed MS, Langer H, Abed M, Voelkl J, Lang F: The uremic toxin acrolein promotes suicidal erythrocyte death. Kidney Blood Press Res 2013;37:158-167.

25 Alzoubi K, Honisch S, Abed M, Lang F: Triggering of Suicidal Erythrocyte Death by Penta-O-galloyl-beta-dglucose. Toxins (Basel) 2014;6:54-65.

26 Arnold M, Lang E, Modicano P, Bissinger R, Faggio C, Abed M, Lang F: Effect of nitazoxanide on erythrocytes. Basic Clin Pharmacol Toxicol 2014;114:421-426.

27 Bissinger R, Malik A, Jilani K, Lang F: Triggering of Erythrocyte Cell Membrane Scrambling by Salinomycin. Basic Clin Pharmacol Toxicol 2014;10.1111/bcpt.12250

28 Borst O, Abed M, Alesutan I, Towhid ST, Qadri SM, Foller M, Gawaz M, Lang F: Dynamic adhesion of eryptotic erythrocytes to endothelial cells via CXCL16/SR-PSOX. Am J Physiol Cell Physiol 2012;302:C644-C651.

29 Ghashghaeinia M, Cluitmans JC, Toulany M, Saki M, Koberle M, Lang E, Dreischer P, Biedermann T, Duszenko M, Lang F, Bosman GJ, Wieder T: Age Sensitivity of NFkappaB Abundance and Programmed Cell Death in Erythrocytes Induced by NFkappaB Inhibitors. Cell Physiol Biochem 2013;32:801-813. 


\section{Cellular Physiology Cell Physiol Biochem 2015;36:773-783 \begin{tabular}{l|l|l}
\hline DOI: 10.1159/000430137 & (C) 2015 S. Karger AG, Basel
\end{tabular}

30 Jilani K, Enkel S, Bissinger R, Almilaji A, Abed M, Lang F: Fluoxetine induced suicidal erythrocyte death. Toxins (Basel) 2013;5:1230-1243.

31 Jilani K, Lang F: Carmustine-induced phosphatidylserine translocation in the erythrocyte membrane. Toxins (Basel) 2013;5:703-716.

32 Lupescu A, Jilani K, Zbidah M, Lang F: Patulin-induced suicidal erythrocyte death. Cell Physiol Biochem 2013;32:291-299.

33 Oswald G, Alzoubi K, Abed M, Lang F: Stimulation of suicidal erythrocyte death by ribavirin. Basic Clin Pharmacol Toxicol 2014;114:311-317.

34 Qian EW, Ge DT, Kong SK: Salidroside protects human erythrocytes against hydrogen peroxide-induced apoptosis. J Nat Prod 2012;75:531-537.

35 Vota DM, Maltaneri RE, Wenker SD, Nesse AB, Vittori DC: Differential erythropoietin action upon cells induced to eryptosis by different agents. Cell Biochem Biophys 2013;65:145-157.

36 Zbidah M, Lupescu A, Jilani K, Lang F: Stimulation of suicidal erythrocyte death by fumagillin. Basic Clin Pharmacol Toxicol 2013;112:346-351.

37 Abed M, Herrmann T, Alzoubi K, Pakladok T, Lang F: Tannic Acid induced suicidal erythrocyte death. Cell Physiol Biochem 2013;32:1106-1116.

38 Alzoubi K, Calabro S, Bissinger R, Abed M, Faggio C, Lang F: Stimulation of suicidal erythrocyte death by artesunate. Cell Physiol Biochem 2014;34:2232-2244.

39 Arnold M, Bissinger R, Lang F: Mitoxantrone-induced suicidal erythrocyte death. Cell Physiol Biochem 2014;34:1756-1767.

40 Bissinger R, Fischer S, Jilani K, Lang F: Stimulation of erythrocyte death by phloretin. Cell Physiol Biochem 2014;34:2256-2265.

41 Bissinger R, Lupescu A, Zelenak C, Jilani K, Lang F: Stimulation of eryptosis by cryptotanshinone. Cell Physiol Biochem 2014;34:432-442.

42 Bissinger R, Modicano P, Frauenfeld L, Lang E, Jacobi J, Faggio C, Lang F: Estramustine-induced suicidal erythrocyte death. Cell Physiol Biochem 2013;32:1426-1436.

43 Jacobi J, Lang E, Bissinger R, Frauenfeld L, Modicano P, Faggio C, Abed M, Lang F: Stimulation of erythrocyte cell membrane scrambling by mitotane. Cell Physiol Biochem 2014;33:1516-1526.

44 Jilani K, Qadri SM, Lang F: Geldanamycin-induced phosphatidylserine translocation in the erythrocyte membrane. Cell Physiol Biochem 2013;32:1600-1609.

45 Lupescu A, Bissinger R, Herrmann T, Oswald G, Jilani K, Lang F: Induction of suicidal erythrocyte death by novobiocin. Cell Physiol Biochem 2014;33:670-680.

46 Lupescu A, Bissinger R, Warsi J, Jilani K, Lang F: Stimulation of erythrocyte cell membrane scrambling by gedunin. Cell Physiol Biochem 2014;33:1838-1848.

47 Malik A, Bissinger R, Calabro S, Faggio C, Jilani K, Lang F: Aristolochic Acid induced suicidal erythrocyte death. Kidney Blood Press Res 2014;39:408-419.

48 Tesoriere L, Attanzio A, Allegra M, Cilla A, Gentile C, Livrea MA: Oxysterol mixture in hypercholesterolemiarelevant proportion causes oxidative stress-dependent eryptosis. Cell Physiol Biochem 2014;34:10751089.

49 Voelkl J, Alzoubi K, Mamar AK, Ahmed MS, Abed M, Lang F: Stimulation of suicidal erythrocyte death by increased extracellular phosphate concentrations. Kidney Blood Press Res 2013;38:42-51.

50 Zhang R, Xiang Y, Ran Q, Deng X, Xiao Y, Xiang L, Li Z: Involvement of calcium, reactive oxygen species, and ATP in hexavalent chromium-induced damage in red blood cells. Cell Physiol Biochem 2014;34:1780-1791.

51 Abed M, Towhid ST, Shaik N, Lang F: Stimulation of suicidal death of erythrocytes by rifampicin. Toxicology 2012;302:123-128.

52 Abed M, Zoubi KA, Theurer M, Lang F: Effect of dermaseptin on erythrocytes. Basic Clin Pharmacol Toxicol 2013;113:347-352.

53 Bottger E, Multhoff G, Kun JF, Esen M: Plasmodium falciparum-infected erythrocytes induce granzyme B by NK cells through expression of host-Hsp70. PLoS One 2012; 7:e33774.

54 Firat U, Kaya S, Cim A, Buyukbayram H, Gokalp O, Dal MS, Tamer MN: Increased caspase-3 immunoreactivity of erythrocytes in STZ diabetic rats. Exp Diabetes Res 2012;2012:316384.

55 Ganesan S, Chaurasiya ND, Sahu R, Walker LA, Tekwani BL: Understanding the mechanisms for metabolism-linked hemolytic toxicity of primaquine against glucose 6-phosphate dehydrogenase deficient human erythrocytes: evaluation of eryptotic pathway. Toxicology 2012;294:54-60.

56 Gao M, Cheung KL, Lau IP, Yu WS, Fung KP, Yu B, Loo JF, Kong SK: Polyphyllin D induces apoptosis in human erythrocytes through $\mathrm{Ca}(2)(+)$ rise and membrane permeabilization. Arch Toxicol 2012;86:741-752. 


\section{Cellular Physiology Cell Physiol Biochem 2015;36:773-783 \begin{tabular}{l|l|l}
\hline DOI: 10.1159/000430137 & (c) 2015 S. Karger AG, Basel
\end{tabular} and Biochemistry Published online: May 22, 2015 \\ Lupescu et al.: Eryptosis in the Elderly}

57 Ghashghaeinia M, Cluitmans JC, Akel A, Dreischer P, Toulany M, Koberle M, Skabytska Y, Saki M, Biedermann T, Duszenko M, Lang F, Wieder T, Bosman GJ: The impact of erythrocyte age on eryptosis. Br J Haematol 2012;157:606-614.

58 Jilani K, Lupescu A, Zbidah M, Abed M, Shaik N, Lang F: Enhanced Apoptotic Death of Erythrocytes Induced by the Mycotoxin Ochratoxin A. Kidney Blood Press Res 2012;36:107-118.

59 Kucherenko YV, Lang F: Inhibitory Effect of Furosemide on Non-Selective Voltage-Independent Cation Channels in Human Erythrocytes. Cell Physiol Biochem 2012;30:863-875.

60 Lang E, Qadri SM, Jilani K, Zelenak C, Lupescu A, Schleicher E, Lang F: Carbon monoxide-sensitive apoptotic death of erythrocytes. Basic Clin Pharmacol Toxicol 2012;111:348-355.

61 Lupescu A, Bissinger R, Jilani K, Lang F: Triggering of suicidal erythrocyte death by celecoxib. Toxins (Basel) 2013;5:1543-1554.

62 Lupescu A, Jilani K, Zbidah M, Lang F: Induction of apoptotic erythrocyte death by rotenone. Toxicology 2012;300:132-137.

63 Polak-Jonkisz D, Purzyc L: Ca Influx versus Efflux during Eryptosis in Uremic Erythrocytes. Blood Purif 2012;34:209-210.

64 Shaik N, Zbidah M, Lang F: Inhibition of $\mathrm{Ca}(2+)$ entry and suicidal erythrocyte death by naringin. Cell Physiol Biochem 2012;30:678-686.

65 Weiss E, Cytlak UM, Rees DC, Osei A, Gibson JS: Deoxygenation-induced and $\mathrm{Ca}(2+)$ dependent phosphatidylserine externalisation in red blood cells from normal individuals and sickle cell patients. Cell Calcium 2012;51:51-56.

66 Zappulla D: Environmental stress, erythrocyte dysfunctions, inflammation, and the metabolic syndrome: adaptations to CO2 increases? J Cardiometab Syndr 2008;3:30-34.

67 Zbidah M, Lupescu A, Shaik N, Lang F: Gossypol-induced suicidal erythrocyte death. Toxicology 2012;302:101-105.

68 Zelenak C, Pasham V, Jilani K, Tripodi PM, Rosaclerio L, Pathare G, Lupescu A, Faggio C, Qadri SM, Lang F: Tanshinone IIA stimulates erythrocyte phosphatidylserine exposure. Cell Physiol Biochem 2012;30:282294.

69 Abed M, Artunc F, Alzoubi K, Honisch S, Baumann D, Foller M, Lang F: Suicidal erythrocyte death in endstage renal disease. J Mol Med (Berl) 2014;92:871-879.

70 Lang E, Gatidis S, Freise NF, Bock H, Kubitz R, Lauermann C, Orth HM, Klindt C, Schuier M, Keitel V, Reich M, Liu G, Schmidt S, Xu HC, Qadri SM, Herebian D, Pandyra AA, Mayatepek E, Gulbins E, Lang F, Haussinger D, Lang KS, Foller M, Lang PA: Conjugated bilirubin triggers anemia by inducing erythrocyte death. Hepatology 2014;10.1002/hep.27338

71 Kempe DS, Ackermann TF, Fischer SS, Koka S, Boini KM, Mahmud H, Foller M, Rosenblatt KP, Kuro OM, Lang F: Accelerated suicidal erythrocyte death in Klotho-deficient mice. Pflugers Arch 2009;458:503-512.

72 Yamamoto M, Clark JD, Pastor JV, Gurnani P, Nandi A, Kurosu H, Miyoshi M, Ogawa Y, Castrillon DH, Rosenblatt KP, Kuro-o M: Regulation of oxidative stress by the anti-aging hormone klotho. J Biol Chem 2005;280:38029-38034.

73 Andrews DA, Low PS: Role of red blood cells in thrombosis. Curr Opin Hematol 1999;6:76-82.

74 Closse C, Dachary-Prigent J, Boisseau MR: Phosphatidylserine-related adhesion of human erythrocytes to vascular endothelium. Br J Haematol 1999;107:300-302.

75 Gallagher PG, Chang SH, Rettig MP, Neely JE, Hillery CA, Smith BD, Low PS: Altered erythrocyte endothelial adherence and membrane phospholipid asymmetry in hereditary hydrocytosis. Blood 2003;101:46254627.

76 Pandolfi A, Di Pietro N, Sirolli V, Giardinelli A, Di Silvestre S, Amoroso L, Di Tomo P, Capani F, Consoli A, Bonomini M: Mechanisms of uremic erythrocyte-induced adhesion of human monocytes to cultured endothelial cells. J Cell Physiol 2007;213:699-709.

77 Wood BL, Gibson DF, Tait JF: Increased erythrocyte phosphatidylserine exposure in sickle cell disease: flow-cytometric measurement and clinical associations. Blood 1996;88:1873-1880.

78 Chung SM, Bae ON, Lim KM, Noh JY, Lee MY, Jung YS, Chung JH: Lysophosphatidic acid induces thrombogenic activity through phosphatidylserine exposure and procoagulant microvesicle generation in human erythrocytes. Arterioscler Thromb Vasc Biol 2007;27:414-421.

79 Zwaal RF, Comfurius P, Bevers EM: Surface exposure of phosphatidylserine in pathological cells. Cell Mol Life Sci 2005;62:971-988. 